\title{
大阪城公園の初期計画における設計者椎原兵市の意図
}

\section{Design Concept of Hyo'ichi Shiihara in the Primary Planning of Osaka Castle Park}

小野 芳朗*

Yoshiro $O N O$

\begin{abstract}
Osaka Castle Park and the tower were rebuilt in 1931 celebrated for the accession of Showa Emperor. The style of the castle tower was studied historical investigation through the building by Prime Minister, Hideyoshi Toyotomi to reconstruct the space of the end of $16 \mathrm{C}$. However, the building as the heritage and the modern equipment coexisted by the construction of a building of Headquarter on Military Army Division. In this paper, an authentic design concept was discussed by a primary designer of Osaka Castle Park, Hyo'ichi Shiihara who was an engineer of Ministry of the Palace and moved to the Osaka City Bureau in 1920 as a chief of Park section. It becomes clear the description of his design concept with Osaka Castle Park by the comparison between a document written in the year when he moved to Osaka City and the one written after the construction of the Park. His primary concept was the construction of the space of the Emperor in Osaka City like to Tokyo, Kyoto and Nagoya, for example, the Palace as the Imperial Villa and the historical museum of the Emperor's family and ancestors. As an engineer of Osaka City, his concept on the Park would change to the one beside the standard shown by the City Planning Bureau of National Government.
\end{abstract}

Keywords: Hyo'ichi Shiihara, Osaka Castle Park, design concept, city planning, Army, Palace キーワード：椎原兵市, 大阪城公園, 設計思想, 都市計画, 陸軍, 宮殿

\section{1. 本論の目的}

大阪城公園は，昭和 6 （1931）年竣工の大阪城天守閣復興とあ わせて整備された。その鉄筋鉄骨コンクリートによる天守閣は, 黒田家所蔵の大坂夏の陣屏風より考証された豊臣期のものである が，実は現存の城郭と天守台が徳川期のものであることは，現在 よく知られている事実である。しかし，竣工当時は豊太閤の城を 復興するという市民の熱意によって，その工事が果たされた。一 方で，その空間は当時の市長、関一のもと進められた「大大阪」, いわゆる法定都市計画による都市改造の象徵空間のひとつでもあ り，大阪市都市計画公園の中に占める代表的公園空間として整備 されることが計画されていた。そして現在も同じく都市計画道路 一等広路となる御堂筋とともに，大阪市のシンボル的空間として の存在感を示している。

さて，大阪城公園については橋寺知子が，明治初年よりその城 郭内の施設についてまとめている。それによると, 病院や舎密局, 学校と, 鎮台, のちの第四師団と砲兵工廠という, 教育・医療と 軍事施設の設置が，これ以降のこの地の市民利用と軍事利用の併 存と競合を生んだといわれる ${ }^{1)}$

一方，昭和 6 年にできる大阪城公園内に，第四師団司令部など 陸軍施設が残存した現実に対して，当初大正 9（1920）年になさ れた大阪城公園計画（当時の大阪市公園課長椎原兵市案）が，陸 軍施設を全く移転させて計画されたことを橋寺は指摘している。 そして，その大正 9 年椎原案の「建築物とそれに伴う造園計画」 は, どちらかといえば「西洋風と判断できる」と橋寺は言ってい る2) 3)。

本論においては資料的には, 橋寺がこれらの記述を，「建築と社 会」昭和 7 (1932) 年 7 月号掲載の, 大阪城公園に関する椎原の 回顧記事 ${ }^{4)}$ のみを基に記されていることに鑑み，この「建築と社 会」の記事と, 新出資料である椎原の大正 9 (1920) 年原案, そ して昭和 6 （1931）年実地設計の公文書資料とを比較検討寸る。 これらの検討により，豊太閤の事蹟を復興するという大阪城の設
計や，橋寺の言う椎原が構想した陸軍施設を排しての「西洋風」 の大阪城公園計画という二つの対立した公園空間イメージに対し て，その設計にあたった椎原の意図の実態と，その空間配置の当 初計画思想に迫ることが本論の主題である。

\section{2. 大阪城天守閣と公園に関する既往研究と本論の史料}

上記に示したように, 橋寺の建築学会における大阪城公園の論 は, 「建築と社会」昭和 7 年 7 月号第 15 輯第 7 号の大阪城天守閣. 第四師団司令部庁舎などの特集号における椎原兵市の記事「大阪 城趾の公園計畫」 ${ }^{4)}$ に拠っている。この中で椎原は，大正 9 年の 当初計画「大阪城趾公園計畫案」が，「史的生命と権威を絶対に尊 重して, 現代の時代精神を加味して適当の設備を施す」コンセプ トの下，本丸の宮殿，記念館，二の丸他の美術館，図書館，社交 場, 音楽堂, 体育館, 植物園, 競技場, 大集会場, 豊国神社など を設けた総計 27 万 6 千坪のものであったことを報告している。

この計画は，城内より陸軍施設を外へ移転するという前提の上 でなされたものであったが，実際には橋寺論文にあるように，陸 軍と共存した形の公園計画 3 万 0707 坪が実施された。それは「歴 史的尊湲を傷つけるやうな一切の施設を避けて城郭の本質を没却 せず，而も城郭美の発揮を助長し得るやうにとの方針」であった と椎原は書いている。しかしながら，実際には豊太閤の時代を再 現し, これに椎原いうところの現代的要素を加味した公園は, 陸 軍施設によって, その趣を異にしたことと橋寺は指摘している2）。

能川は5)，陸軍史料を基に大阪城天守閣復興について記述して いる。それによると,「陸軍との数度にわたる交渉を経て, 大阪市 が師団司令部庁舎を新築し，それを陸軍に寄付することを条件に 承諾を得たうえで, 右のような計画が関市長によって一九二八年 七月一四日の市会に提案され，「満場一致」で可決」したとある。 昭和 3（1928）年市会において最終決定した大阪城天守閣を含む 公園案は, 城内の陸軍施設の大阪市による新築を条件としていた。 この当初の天守閣を含む城内施設の管轄は, 大阪市土木部公園課

*京都工芸䋊維大学大学院工芸科学研究科建築造形学部門 
6) であり，公園課長は椎原兵市であった。つまり，天守閣そのも のの建築は, 先述したように黒田家什物「大坂陣絵屏風」を考証 して，大阪市建築課長波江悌夫が設計するものの，天守閣を含む 城内の公園化の主導は市公園課にあり，その中心が椎原兵市であ った。

陸軍施設，才なわち第四師団司令部庁舎は，昭和6（1931）年 に陸軍の設計によって本丸城内に新築されたが，大正 9 (1920) 年の「大阪城趾公園計畫」では城外一移転することが交渉されて いたことを, 酒井は大正 9 年の「建築世界」を基に述べている7)。 また天守閣に関して，前記「建築と社会」昭和 7 (1932) 年 7 月 号の「特輯三建築を主題として」 ${ }^{8)}$ と称する座談会の記事から, 当初椎原の大正 9 年案では，天守台に「天守閣の小さいもの」を 造る計画であったものを，後藤新平が大正 14（1925）年の大大 阪博覧会時の天守台の豊公館に想を得て，天守閣復興を関一市長 に進言したことにより，復興構想が本格化したこと，さらに市長 は御大典事業として天守閣の鉄筋鉄骨コンクリートでの築造があ げられたこと，そしてそのことは軍部による働きかけがあったの ではないか, と酒井は推論している。この「建築と社会」におけ る座談会は，天守閣設計者の波江悌夫，富士岡重一，公園設計者 の椎原, そして武田五一, 徳政金吾, 池田實, 涉谷眞弓, 南信, 古塚正治, 高橋栄治が参加したが, 陸軍第四師団庁舎のデザイン に対する批判が相次ぎ，そのためか発言者はA， B， C・・・の 匿名に伏されている。その批判内容の要諦は，ひとつは大正 9 年 当初案の陸軍施設を除いた大阪城公園を造ることが結果的にかな わず，師団司令部を本丸に造ったことを惜しむこと，そしてその デザインが中世の城郭風で，桃山時代を強調したい復興大阪城の 傍にはふさわしくない（当時，天守台や城郭が徳川時代のものと は認識されていなかった)，と表明し，「如何にも建築家として不 用意であったと云われても致し方はない，その出来不出来のこと は第二として基礎感念に甚だ疑を持った」の発言もある。これら の発言からは，本丸には江戸時代の紀州御殿や，明治時代の近代 都市施設である水道貯水池があるものの, 「天守閣」ひとつにより 桃山時代の空間を再現したい，との意図がみえてくる。一方，陸 軍の設計者である平田範政は，同号誌上でこうした座談会の意見 とは異なる見解を示している。いわく,「同一様式の所謂日本建築 に仕様と云ふアカデミツクな思想は勿論設計の当初に於て第一に 想起したのであつたけれども（中略）本建築は純然たる事務所で あり（中略）徒に耽美と骨董に溺し新しき時代の事務所たるべき 建築本来の使命を冒瀆するものであるとの決断の下」設計したと ある。

このように本丸内の天守閣と第四師団司令部は，文化財と軍施 設といら相反するテーマを共存したことになっている。しかしな がら，他にも明治 $30 （ 1897 ）$ 年の大阪市水道開設によって市内 の高台として本丸内に造られた「水道貯水池」つまり配水池は天 守閣の真横にあり, 紀州御殿は明治 18 (1885) 年和歌山城二の 丸御殿の書院を移築しており，ただ復興した鉄筋の天守閣と師団 司令部のデザイン的対比というだけでなく，本丸内はすでに文化 施設とともに近代都市施設が共存していたのである。それでも座 談会の出席者たちのこの空間への思いは天守閣復興のために寄付 をした大阪市民の気分を代表するように，「太閤秀吉の空間」の本 丸であった。

ところで，同座談会において椎原は，大正 9 （1920）年の直木 倫太郎部長による公園化への指示があったことを事の発端として いるだけで，他の出席者のように陸軍施設が残存したことや，司 令部庁舎のデザインなどに不満の形跡はみせておらず，その設計 意図に関して明言を避けている。そこで本論では，既報や完成当 時の座談会にみるように, 大阪城公園は太閤秀吉の空間として復 興するものの，陸軍施設（近代施設）と対立的に共存していくこ
とになった，という構図に対して，そもそもの大阪城公園当初計 画の主任設計者であった椎原兵市の意図に着目する。そこで，京 都工芸䋊維大学美術工芸資料館の椎原兵市コレクション中の椎原 自身により書かれ，かつ改訂の付箋も加えられている「大阪城趾 公園設計梗概」9）と，昭和6（1931）年の実地設計で大阪市公文 書館蔵の「大阪城公園施設承認方ノ件」10) のいずれも 1 次資料を 比較することにあり，ここまでみてきた刊行書，研究事例には書 かれていない椎原の設計の意図を次章以下で明らかにする。

\section{3. 都市計画上の大阪城公園と椎原の経歴}

大阪城公園は先述したとおり，昭和 3 (1928) 年の昭和御大典 記念事業として整備された。一方，都市計画法施行に伴う公園整 備事業がす寸められていた。当時の公園は, その構造や用途, 施 設の定義よりも公園 (緑地)の面積基準を満たすことが優先され, 大正 13 （1924）年の第 1 回都市計画主任官会議で内務省都市計 画局第二技術課私案により 1 人 2 坪（1500 人当たり $1 \mathrm{ha} ）$ の標 準が示されていた。これに準じようとした地方都市11ももあたが， 大阪市はこの時 1 人 2 坪は実現不可として， 1 人 1 坪で実施する と回答していた ${ }^{12)}$ 。この面積の中には大阪城公園も含まれ，昭和 3 （1928）年には「総合大阪都市計画」中の公園計画として立案 される。大阪城公園も，第十二号公園として数えられていた 13 。 豊太閤の空間の復興や，陸軍施設の排除を理念とした大阪城公園 の当初案 23 万 6 千坪計画の背景には, 内務省指示の都市計画公 園としての面積確保の側面もあった。それは，大阪城公園並びに 大阪市の都市計画公園双方の立案者である椎原自身が，「在来の 公園面積に将来の公園面積を加一，今後二十ヶ年後に於ける市民 一人当たりの公園面積を約一坪に近からしむる事を目標として立 案」した，との昭和 3 年時点での証言により明らかである ${ }^{14) 。 ~}$

その椎原兵市は, 明治 41 (1908) 年京都高等工芸学校図案科 を卒業後, 宮内省内苑寮にて市川之雄技師と, 離宮庭園, 京都御 苑，御用邸などの宮廷庭園をはじめ，伊勢神宮や出雲大社，招魂 神社などの外苑設計などを手がけた。その後大正 9 (1920) 年武 田五一が大阪市都市計画事業の顧問に就任するに及び，弟子の椎 原を大阪市に紹介し, 初代公園課長として大小 88 箇所の公園設 計をするに及んだ ${ }^{15)}$ 。

\section{4. 椎原の大阪城公園設計の意図}

それでは，椎原の大阪城公園設計原案では，どのような空間を 設計しょうとしたのであろうか。それは椎原が「建築と社会」に 寄稿した文章 ${ }^{4 ）}$ と，大正 9 年の「設計梗概」9）とを比較すること によって明らかとなる。椎原は「史的生命」の上に「現代の時代 精神を加味」して, 前述したように宮殿 (紀州御殿) などを配置 する計画をもっていた。この「建築と社会」一寄稿された文は, 原文である「設計梗概」から，ある部分を修正したり，削除して 寄稿されている。たとえば，「教育的な公園として旁に大阪市の一 名勝たるに止まらず、帝国の誇りとするに足る」の部分では，「帝 国」を「我が国」と修正している。また原文の削除部分には，「忠 孝義勇习重ンジ国民精神ヨ発揚」を実現すべく，「国民尊崇ノ中心 タル我皇室ノ御用二充テ奉ルベキ宮殿卜併セテ皇室御歴代ノ功業 ヨ追憶シ奉ルベキ記念館」を作るという箇所がある。それらは, 「将来皇室ノ御用二充ツベキ宮殿ヨ増築シ折ニフレテハ行幸啓ヨ 迎へ奉リ又或時八一部习外国貴賓ノ旅館二モ用ユベク且ツ附近二 記念館习建築シテ国史ノ実物教材ヨ提供シ市民ヨシテ常ニ之二接 触セシメナバ不知不識ノ間二忠良ナル国民精神习涵養スルラ得」 るためと書かれている。「建築と社会」記事では単に記念館とした のは，皇室史記念館であった。また武徳殿も当初あがっていたが 省かれている。またそこには座談会で話題となった, 豊臣秀吉の 空間を再現する，とは書かれていないことが興味深い。 


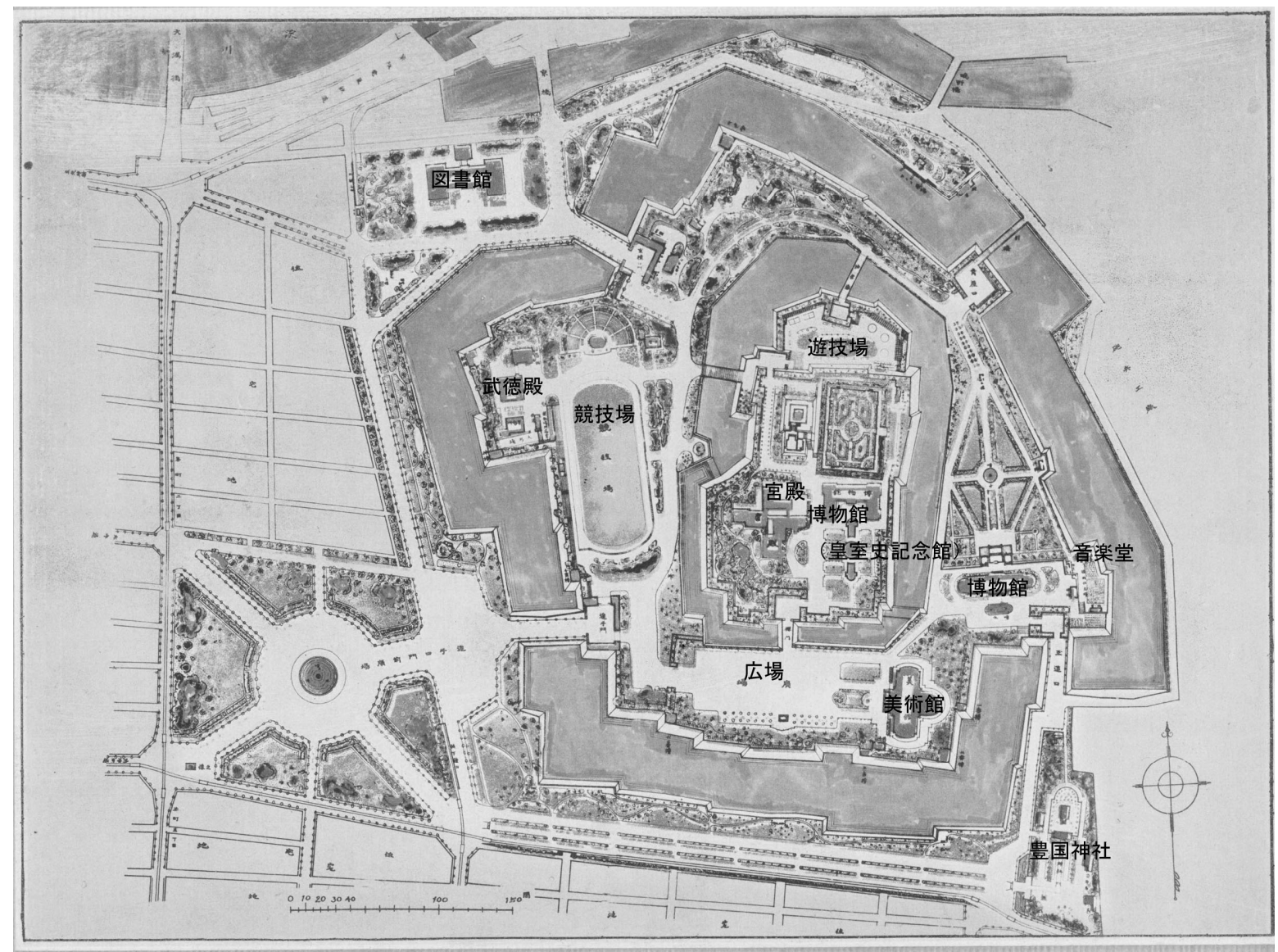

図 - 1 大阪城公園 大正 9 年椎原原案

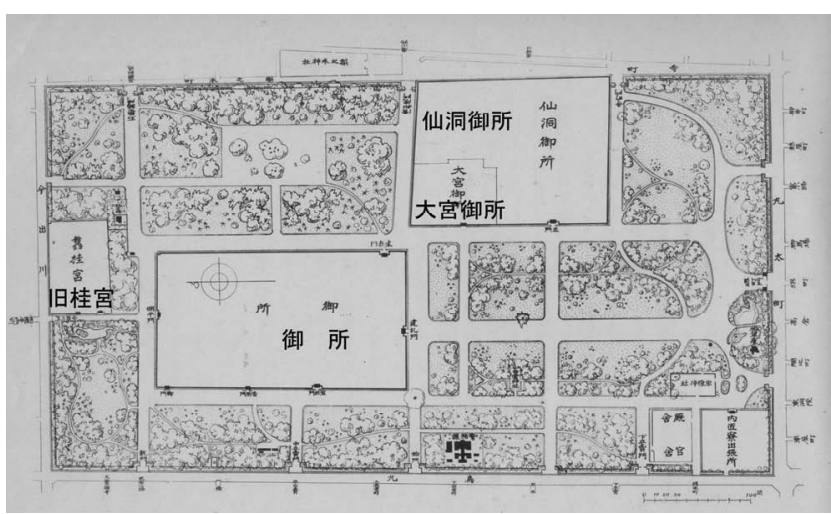

図 - 2 京都御苑 大正 4 年 椎原設計

また, 原文には万年筆による自筆の付箋による加筆部分がある。 それには本丸北東の砲兵工廠の移転を前提に，そこに城内の競技 場，遊技場を移転し，「城内八古城跡トシテ可成旧体习損セザル様 荘㛜ノ光景习保存センコソ設計者ノ緊切ニ希望スル所」とある。 一方の, 実地設計である大阪市による昭和 6 年の「大阪城公園施 設概要説明書」10）の内容は，そのまま昭和 7 年「建築と社会」の 記事 ${ }^{4)}$ と一致している。

こうしたことから，椎原の当初案は皇室の権威を高めるための 迎賓館ともなる宮殿，皇国史の展示館という天皇の空間を本丸内 に構築することに力点が置かれていたことがわかる。昭和 7 （1932）年時点での椎原の回顧による陸軍司令部庁舎との共存や, 砲兵工敞の移転不可などで計画全体が縮小される中で，皇室色は 緩和され，美術館，図書館，博物館など市民施設と横並びで語ら れていく。橋寺はこれを，むしろ「西洋風と判断」できると論じ

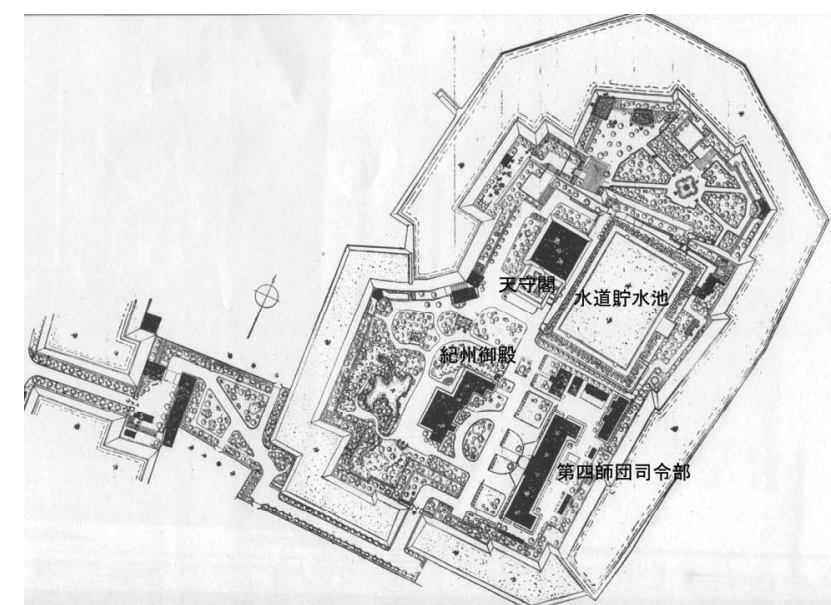

図 - 3 大阪城本丸実地設計 昭和 3 年 大阪市公園課

たが, 以上の原文からの椎原の当初の意困は，「皇室の空間として の大阪城」であり, 天守閣復興も未だ企図されていないので、豊 臣秀吉の空間の再現でもなかったと指摘することができる。

大正 9 年時点での椎原の大阪城公園計画の全体図が, 彼の著作 である「現代庭園図説」16) に掲載されており，それを図-1に示寸 (図には文中にない博物館・遊技場が記されている)。「建築と社 会」の椎原の記事には同図の一部分が掲載されており, 橋寺はそ れを引用しているが, 全体図から見ると, 本丸内には天守閣と宮 殿 (紀州御殿の改造), 皇室史記念館(図中で本丸の博物館に相当), 水道貯水池の上は洋風公園化されている。本丸内は天皇と皇室の 空間として強調した。貯水池の洋風公園も, 椎原が大正 4 (1915) 
年に設計した京都御苑の遊歩道と植栽をイメージさせる構成とな っている (図-2 京都御苑 $\left.{ }^{17}\right)$ )。天守閣の夕に着目寸ると, そこ は豊太閤の再現空間となるが，関白太政大臣という天皇の藩屏の 一人者である豊臣秀吉の城を宮殿の脇に復興して添えた空間と見 ることもできる。そして，豊国神社は南東の外苑に配しており， その外苑に向かっては美術館，図書館，博物館（二の丸のもの） などの市民施設を分散させていく椎原の設計意図が明らかである。 この設計初期における椎原の意図が何に由来するのか，明示す る資料はない。高橋は ${ }^{18)}$, 京都工芸䋊維大学の椎原の図面コレク ションから，その平面図の意味と役割を論じているものの，宮内 省時代から大阪市時代にかけて平面図に書き込まれる情報が増加 することを, 実務家としての業務の範囲と規模が拡大したからだ, ということのみで説明しており，椎原自身の持つ設計思想の背景 には触れるに至っていない。

本論では，大正 9 年時点の椎原の初期設計案と、昭和 7 年の大 阪城公園開設後の椎原の記述の差から、当該公園設計の意図を読 み取ろうとした。何故、椎原は当初設計にある「設計梗概」の原 文から、本論で指摘した部分を削除して「建築と社会」に掲載し たのか。そして、何故座談会において他の出席者のように陸軍の 設計を非難しなかったのか。

削除、修正された部分に書かれていたのは、先にもみたように 「帝国」の空間を大阪に構築することであった。削除部分にはま た「大阪市八商工業ノ中心トシテ他二比類ナキ盛況习檀二ス卜雖 モ東京、京都、名古屋等各市二比シ畏レ多キ事ナガラ皇室二関ス ル縁故近時甚ダ浅キノ感アリ」9)とあり、皇居、離宮を有する都 市に大阪を並べることが意図されている。そして、その公園のデ ザインは、「近代天皇」の空間を強調する為に、復古調ではない、 西洋風のスタイルとした。秀吉の天守閣は当初は予定されていな かった。

大正 9 年時点での椎原は、宮内省から請われて大阪市に赴任し たばかりで、その最初の大きな仕事が大阪城公園の設計であった。 この年、大阪市の都市計画は端についたばかりであった。その実 施母体となる都市計画大阪地方委員会も、この年は 9 月 9 日の第 一回だけで、規則と組織を定めたのみであった。つまり、大正 9 年の椎原は、まだ宮内省内苑寮技師の視線で大阪城を捉え、皇居 や名古屋離宮 (名古屋城)、二条離宮、彼が自ら設計を手掛けた京 都御所と同列に大阪城を設計することを考えたとみることができ る。

しかしながら都市計画が実施されていくに及んで、「公園」の設 計標準は、内務省の指示により面積標準を達成することが一義で あり、それを求めることが大阪市公園課長の椎原の責務となる。 そのことは前記したように、彼自らが昭和 3 年に語っている。公 園は都市計画の中では、都市を構成する一施設であった。大阪城 公園、すなわち都市計画公園第 12 号という現実の中で、設計・ 実施の報告書となった昭和 7 年「建築と社会」記事では、椎原は 大正 9 年時点での「皇室の空間」の当初思想を削除して、復興さ れた大阪城の外苑地としての公園と表現したと考えられる。「建 築と社会」座談会で、場の主題が「豊太閤の桃山時代」の空間再 現を標榜し、一方で陸軍司令部の欧州の古城様式が非難される中 で椎原は沈黙していた。そもそも「皇室の空間」を目指していた 椎原からすれば、豊太閤の天守閣は後から加えられた構造物であ り，陸軍施設は大元帥たる天皇の幕下の施設であり、違和感のあ るものではなかったとも推察することができる。

\section{5. 結論}

陸軍施設の排除を企図しながら，結果的に昭和御大典時の天守 閣復興と公園整備が陸軍との共存になった大阪城公園について, その公園の設計の意図を, 設計者の原文である設計書より論考し た。
結果としてできあがる大阪城公園施設（図- $3^{4)}$ ) は，大正 9 年 当初は宮殿, 記念館を中心に, 美術館, 図書館, 体育館など市民 施設が当初横並びで企画されたと公開された。しかしながら、こ の昭和 7 年に完成後の大阪城公園と天守閣を扱った「建築と社会」 の記事と、本論で新出資料として提示した大正 9 年の椎原の原案 を比較した結果、以下のようなことが分かった。原案には「建築 と社会」記事には掲載されていない文章が存在した。そこには、 大阪城公園として「皇室の空間」を構築する計画が書かれてあつ た。それは宮内省から同年に大阪市に移動した椎原が、宮内省で 培ってきた設計思想であったとも考えられる。しかし、都市計画 公園は内務省から 1 人当たりの面積を確保寸る「物理的な空間」 として設定された。大阪城公園も都市計画公園として設計・編入 することが、市公園課長の椎原の仕事であった。宮内省内苑寮技 師として皇室の視線を持っていた椎原が、都市計画技師として内 務省標準などに従った結果が、大正 9 年「設計梗概」と、昭和 6 年「施設概要」、昭和 7 年「建築と社会」の差となって表れたと 結論付けることができる。そして, 大正 14 年の後藤新平の発案 により天守閣復興がなされた為に，大阪城が豊太閤の空間として 汎く意識されるようになったと考えられる。

\section{補注及び引用文献}

1）橋寺知子. 川道麟太郎（2003）: 明治初年に大坂城址に設置された近代的施設につい て:日本建築学会計画系論文集，568，179-184

2）橋寺知子（2002）:大正期の「大阪城公園」計画と昭和期に実現した大阪城公園につ いて: 日本建築学会大会学術講演梗概集 (北陸)，441-442

3）橋寺知子（2002）:開園時の大阪城公園と大正期の計画案について:日本建築学会近 畿支部研究報告集, 1029-1032

4）椎原兵市 (1932）: 大阪城址の公園計画:建築と社会, 15 (7), 37-43

5) 能川泰治 (2009) : 大阪城天守閣復興前史 - 陸軍史料に見る大阪城の観光地化と浪速 神宮問題 - : 大阪の歴史, 73, 83-116

6) 北川央 (1999) : 大阪城天守閣 - 復興から現在に至るまで - :歴史科学, 157, 14-24. そのほか, 大阪城の歴史については, 渡刃武 (1983) : 再版増補 図説再見大阪城, 大阪都市協会や天守閣復興については, 牧英正 (1993) : 昭和の大阪城天守閣築造: 大阪市公文書館研究紀要五に詳しい

7) 酒井一光 (2007) : 大阪城天守閣復興と城内の聖域化: 大大阪イメージ, 創元社, 56 $-77$

8）波江悌夫. 椎原兵市ら（1932）:特輯三建築を主題として:建築と社会, 15 (7), 89 $-109$

9）椎原兵市（1922）：大阪城跡公園設計梗概: 大阪市役所都市計画部，大正九年七月計 按, 京都工芸䋊維大学美術工芸資料館蔵，AN. 4822-bis-1-13

10）大阪市（1929）:案土甲三八○一号、大阪城公園施設承認／件，大典記念大阪城公 園施設概要説明書: 都市公園台帳 - 大阪城公園, 昭和四年 十年, 35998, 大阪市公 文書館蔵

11）小野芳朗 (2011) : 戦前の都市計画法適用下における岡山後楽園と公園計画:日本建 築学会計画系論文集, 659, 253-259. 布山修作. 木方十根 (2009) : 旧都市計画法下. 鹿児島公園計画の計画手法について: 日本建築学会計画系論文集，644，2165-2172 12)内務省（1923）:都市計画会議:都市公論, 7 (7) ,33-87 13) 大阪市 (1928) : 大阪都市計画圖 - 街路·運河·公園·墓地: 大阪府立中之島図書館蔵 14)椎原兵市 (1928) :我が大大阪の計画成る:大大阪, 4 (8), p24 15) 同出版委員会：(1966）：椎原兵市氏の作品と業績 16)椎原兵市（1924）：現代庭園図説，p125 17)椎原兵市 (1924）：現代庭園図説，p7 18)高橋宏樹. 宮城俊作 (2000) : 椎原兵市の遺した図面からみた戦前の造園設計におけ る平面図の意味と役割:ランドスケープ研究，63 (5)，753-758 